\title{
41. CALCAREOUS PLANKTON PLIOCENE-PLEISTOCENE BIOSTRATIGRAPHY IN THE TYRRHENIAN SEA (WESTERN MEDITERRANEAN, LEG 107) ${ }^{1}$
}

\author{
G. Glaçon, ${ }^{2}$ D. Rio, ${ }^{3}$ and R. Sprovieri ${ }^{4}$
}

\begin{abstract}
The distribution of stratigraphically important calcareous nannofossils and planktonic foraminifera has been investigated in the Pliocene-Pleistocene sequences of ODP Sites 652, 653, and 654 (Tyrrhenian Sea-western Mediterranean). Semiquantitative and quantitative methods have been used, and an optimum relative sequence of bioevents based on the calcareous plankton groups has been established. About 30 bioevents in an interval of 5.0 m.y. are considered widely traceable in the area and reasonably synchronous. On the basis of those events, a correlation among the three investigated sequences is presented.
\end{abstract}

\section{INTRODUCTION}

The drilling campaign of ODP Leg 107 in the Tyrrhenian Sea (western Mediterranean) had as one of its main target the Tyrrhenian Sea as a biostratigraphic type locality. The stratotype sections of all the chronostratigraphic units of the Pliocene and Pleistocene used are located in the circum-Tyrrhenian area. The recovery of a continuous and complete pelagic Pliocene-Pleistocene sequence was considered extremely important as a deep-sea Mediterranean type section in which to cross-correlate various fossil group biostratigraphies with tephrochronology and stable isotopic stratigraphy. Hole 653A, drilled near DSDP (Deep Sea Drilling Project) Site 132 was specially dedicated to this stratigraphic objective. Sites 652 and 654 , respectively southeast and northwest of Site 653 (Fig. 1), also recovered fairly complete Pliocene-Pleistocene sequences, useful for the same stratigraphic purpose. In this paper we present the results of an integrated study of calcareous nannofossils and planktonic foraminifers at Sites 653,652 , and 654 . The succession of biostratigraphic events provided by the two fossil groups is cross-correlated in order to check traceability and ranking of the events in the Tyrrhenian Sea and to establish an optimum sequence of calcareous plankton events in the western Mediterranean basin.

\section{MATERIALS}

Site 652 is located on the lower Sardinian continental margin $\left(40^{\circ} 21.30^{\prime} \mathrm{N}, 12^{\circ} 08.59^{\prime} \mathrm{E}\right)$, at $4466 \mathrm{~m}$ depth (Fig. 1). The Pliocene-Pleistocene sequence is $188 \mathrm{~m}$ thick. Recovery was poor, with several long gaps. Site 653 is located one-half mile northeast of DSDP Site 132, on the eastern rim of the Cornaglia basin, at $2817 \mathrm{~m}$ depth $\left(40^{\circ} 15.86^{\prime} \mathrm{N}, 11^{\circ} 26.99^{\prime} \mathrm{E}\right)$. The PliocenePleistocene sequence is $211 \mathrm{~m}$ thick. Recovery was good with only few, short unrecovered intervals. Site 654 was drilled on the upper Sardinian margin, at $2208 \mathrm{~m}$ depth $\left(40^{\circ} 34.76^{\prime} \mathrm{N}, 10^{\circ} 41.80^{\prime} \mathrm{E}\right)$. The Pliocene-Pleistocene sequence is $242.7 \mathrm{~m}$ thick. Recovery was poor, with several gaps.

Planktonic foraminiferal analysis was carried out on samples at $15,31,75,91$, and $135 \mathrm{~cm}$ of each section at Hole $653 \mathrm{~A}$, and samples at 15, 36, 75, and $90 \mathrm{~cm}$ at Holes 652 and 654. Calcare-

\footnotetext{
${ }^{1}$ Kastens, K. A., Mascle, J., et al., 1990. Proc. ODP, Sci. Results, 107: College Station, TX (Ocean Drilling Program).

${ }^{2}$ Laboratoire de Stratigraphie et de Paleoecologie, Université de Provence, Place Victor Hugo, Marseille, France.

3 Istituto di Geologia, Via Kennedy 4, Parma, Italy.

${ }^{4}$ Department of Geology and Geodesy, Corso Tukory 131, Palermo, Italy.
}

ous nannofossils were studied in samples at 15 and $75 \mathrm{~cm}$ at Sites 652 and 654 . A closely spaced set of distinct samples (reported in Rio, Raffi, and Villa, this volume) was studied at Site 653.

\section{METHODS}

For the analysis of planktonic foraminifers, dried sediment of each sample was macerated in water and then washed on a $63-\mu \mathrm{m}$ sieve. Semiquantitative analysis was performed on the residue greater than $125 \mu \mathrm{m}$ to obtain the distribution of planktonic foraminifers.

Sample preparation for the calcareous nannofossil study followed standard procedures. Light microscope techniques were utilized, except in the late Pleistocene interval of Hole 653A, where nannofossils were analyzed by Scanning Electron Microscope (SEM) to detect Emiliania huxleyi. Calcareous nannofossil biostratigraphic events were detected by using the same quantitative analysis techniques and event definitions described in Rio, Raffi, and Villa (this volume).

In the range charts of Figures 2, 3, and 4, the events (FO, First occurrence; LO, Last occurrence; FAD, First appearance datum; LAD, Last appearance datum; FCO, First common occurrence; LCO, Last continuous occurrence) occurring at the base or at the top of an unrecovered interval are placed in the middle part of the pertinent underlying or overlying unrecovered interval. Because of the close sample spacing, the biostratigraphic events of the planktonic foraminifers are positioned at the level where they are detected. Any biostratigraphic event of the calcareous nannofossils is placed midway the levels where it has been found and the next underlying or overlying one.

\section{RESULTS}

\section{Calcareous Nannofossils}

Calcareous nannofossil distributions at ODP Hole 653A are reported in detail in Rio, Raffi, and Villa (this volume). The distribution patterns of calcareous nannofossils in Sites 652 and 654 have been studied by Rio (in collaboration with Raffi, I. and Belli, A.). Detailed results of the analysis of these two sites will be published elsewhere. For the present paper, we report in Table 1 and in Figures 2, 3, and 4 the levels of all the calcareous nannofossils biostratigraphic events useful for biostratigraphic correlation and classification. In Sites 652 and 654, the distribution of Emiliania huxleyi has not been monitored. The biostratigraphic scheme of Raffi and Rio (1979) amended in Rio, Raffi, and Villa (this volume) has been utilized for zonal assignments. This scheme is compared with the "standard" zonations of Martini (1970) and Okada and Bukry (1980) in Figure 1 of Rio, Raffi, and Villa (this volume). It has been adopted here because it allows a much higher resolution in the Pleistocene interval and it is more easily applied in the western Mediterranean stratigraphic record. 


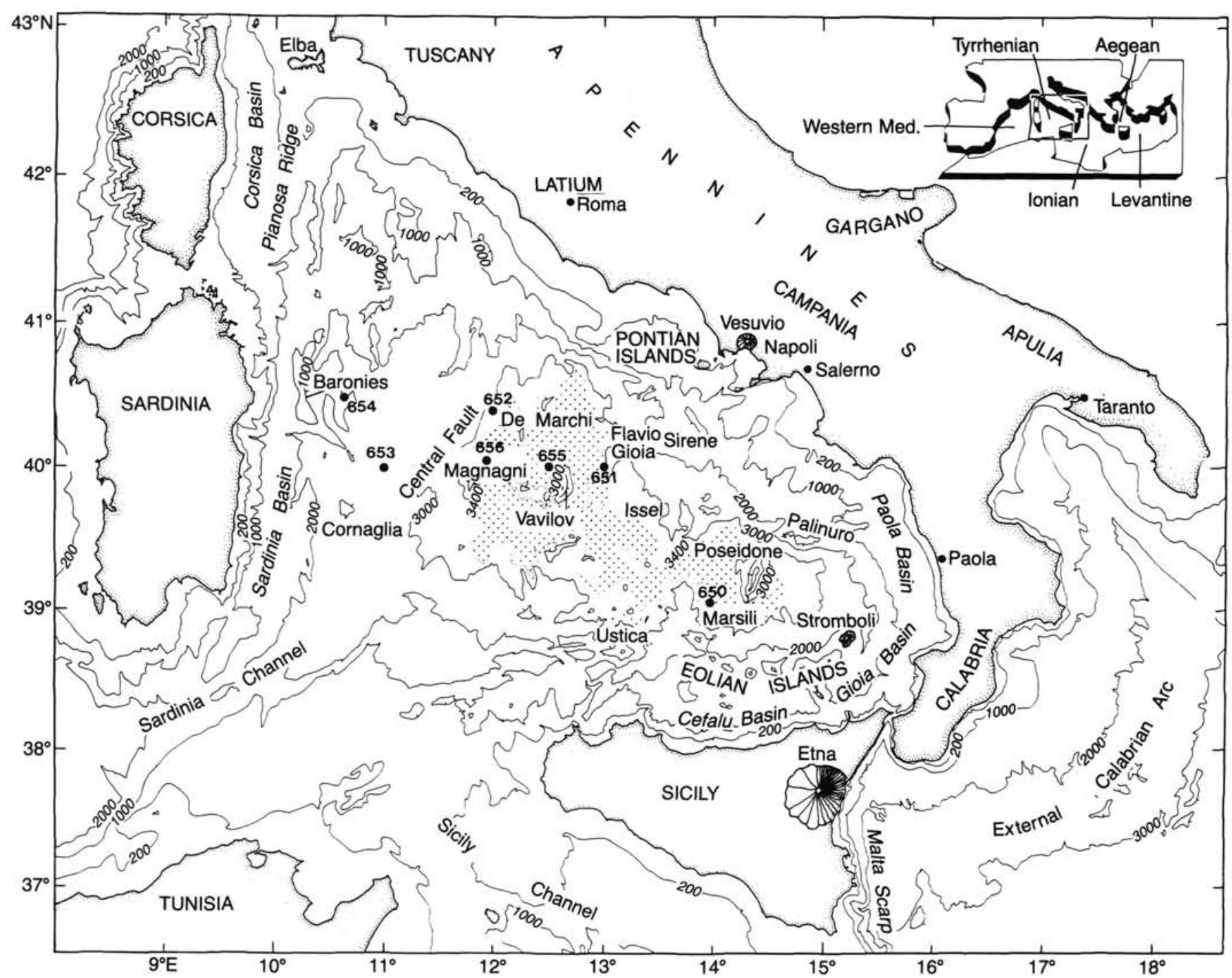

Figure 1. Location map of the studied sites.

\section{Planktonic Foraminifers}

The Pliocene biostratigraphic scheme for the Mediterranean planktonic foraminifers proposed by Cita $(1973,1975)$, as emended by Rio et al. (1984a), has been adopted. Although more detailed biostratigraphic subdivisions can be made, this scheme is still the best suited for the Pliocene biostratigraphy of the deep-sea record. The Pleistocene biostratigraphy proposed by Ruggieri et al. (1984) was also adopted.

\section{Site 653}

The near complete recovery in Hole $653 \mathrm{~A}$ allowed very detailed biostratigraphic resolution, based on analysis of 327 samples. Unfortunately, near the base of the Pliocene sequence, the sampling was switched from Hole $653 \mathrm{~A}$ to Hole $653 \mathrm{~B}$. The correlation between Sample 653A-23, CC, and Sample 653B-23-4, $75 \mathrm{~cm}$, is assured by the end of the acme of Sphaeroidinellopsis spp. that occurs in the two levels. The very base of the MPI1 biozone (Sphaeroidinellopsis spp. biozone) is not represented in Hole $653 \mathrm{~B}$. It is probably present in Hole $653 \mathrm{~A}$, considering the greater thickness of the interval characterized by the acme of Sphaeroidinellopsis spp. recognizable in Hole 653A (all of core 23). In Figure 2 the range chart of selected species is reported with the biostratigraphic and chronostratigraphic subdivision of the sequence. In Table 2, the samples and depth below seafloor (mbsf) of the main biostratigraphic events are reported. Comments on the distribution of selected taxa follow below.

Globorotalia margaritae appears in Sample 23-5, $91 \mathrm{~cm}$ (208.96 mbsf), $3 \mathrm{~m}$ above the end of the acme of Sphaeroidinellopsis spp. (Sample 653A-23-CC; $211.90 \mathrm{mbsf}$ ). At the base of its range $G$. margaritae is characterized by a short interval (up to Sample $22-3,75 \mathrm{~cm} ; 205.80 \mathrm{mbsf}$ ) in which the species is rare and scattered. From this level upwards, G. margaritae is abundant and continuously present in the samples. The same feature is recognized at the extinction level of the species. Above its common and continuous occurrence (up to Sample 19-1, $75 \mathrm{~cm}$; $164.85 \mathrm{mbsf}$ ), the species is sparse and discontinuous up to Sample $17-6,15 \mathrm{~cm}$ (153.26 mbsf) whereafter it definitively disappears. The FO and LO of this species are placed at the first and last rare occurrences.

The appearance of Globorotalia puncticulata is in Sample $21-3,15 \mathrm{~cm}$ (186.35 mbsf) and is coincident with the base of MPl3 biozone (Globorotalia margaritae-Globorotalia puncticulata biozone). This event is easily detected and is characterized by the presence of common specimens from the basal sample of its range interval. Rare to few specimens in Sample 21-5, $136 \mathrm{~cm}$ 
Table 1. Samples and depth intervals of the main calcareous nannofossil biostratigraphic events.

\begin{tabular}{|c|c|c|c|c|c|c|}
\hline & \multicolumn{2}{|c|}{ Site 652} & \multicolumn{2}{|c|}{ Site 653} & \multicolumn{2}{|c|}{ Site 654} \\
\hline & Samples & $\begin{array}{l}\text { Depth } \\
\text { (mbsf) }\end{array}$ & Samples & $\begin{array}{l}\text { Depth } \\
\text { (mbsf) }\end{array}$ & Samples & $\begin{array}{l}\text { Depth } \\
\text { (mbsf) }\end{array}$ \\
\hline \multirow[t]{2}{*}{ Acme E. huxleyi base } & & & $1-4,25$ & $3.70(?)$ & & \\
\hline & & & $\begin{array}{l}2-1,60 \\
3-2,60\end{array}$ & & & \\
\hline \multirow[t]{2}{*}{ E. huxleyi FAD } & & & & $15.60 \pm 0.30$ & & \\
\hline & & & $\begin{array}{l}3-2,120 \\
4-5,25\end{array}$ & & $\begin{array}{l}2-4,36 \\
4-2,8\end{array}$ & \\
\hline \multirow[t]{3}{*}{ P. lacunosa LAD } & & $11.10 \pm 6.2$ & & $29.12 \pm 0.17$ & & $23.28 \pm 0.3$ \\
\hline & $3-1,45$ & & $4-5,60$ & & $4-2,68$ & \\
\hline & $5-1,14$ & & $7-6,25$ & & $5-3,9$ & \\
\hline \multirow[t]{3}{*}{ Gephyrocapsa sp. 3 FAD } & & $41.40 \pm 4.9$ & & $58.92 \pm 0.17$ & & $34.64 \pm 0.75$ \\
\hline & $6-1,55$ & & $7-6,59$ & & $5-4,9$ & \\
\hline & $5-1,14$ & & $7-6,25$ & & $5-3,9$ & \\
\hline \multirow[t]{2}{*}{ End dominance Small Gephyrocapsa } & & $41.40 \pm 4.9$ & & $58.92 \pm 0.17$ & & $34.64 \pm 0.75$ \\
\hline & $\begin{array}{l}6-1,55 \\
6-1,128\end{array}$ & & $\begin{array}{l}7-6,59 \\
8-3,120\end{array}$ & & $\begin{array}{l}5-4,9 \\
6-6,10\end{array}$ & \\
\hline \multirow[t]{3}{*}{ Base dominance Small Gephyrocapsa } & & $51.50 \pm 4.41$ & & $64.97 \pm 0.27$ & & $53.50 \pm 5.65$ \\
\hline & $7-1,50$ & & $8-4,25$ & & $8-1,10$ & \\
\hline & $6-1,128$ & $5150+441$ & $8-4,25$ & $6542+017$ & $6-6,10$ & $535+565$ \\
\hline \multirow[t]{2}{*}{ H. sellii LAD } & $7-1,50$ & $31.50 \pm 4.41$ & $8-4,58$ & $03.42 \pm 0.17$ & $8-1,10$ & $30.5 \pm 3.03$ \\
\hline & $7-4,50$ & & $9-3,60$ & & $8-2,70$ & \\
\hline \multirow[t]{3}{*}{ Gephyrocapsa $>5.5 \mu \mathrm{FAD}$} & & $62.50 \pm 2.13$ & & $73.8 \pm 0.2$ & & $61.70 \pm 0.52$ \\
\hline & $8-1,36$ & & $9-3,100$ & & $8-3,10$ & \\
\hline & $8-2,65$ & $6650+014$ & $10-1,60$ & $80.27+0.08$ & $9-2,70$ & $71.90+0.45$ \\
\hline \multirow[t]{2}{*}{ C. macintyrei LAD } & $8-2,93$ & $00.30 \pm 0.14$ & $10-1,75$ & & $9-3,10$ & \\
\hline & $10-1,68$ & & $10-4,120$ & & $9-3,70$ & \\
\hline \multirow[t]{3}{*}{ G. oceanica s.l. FAD } & & $85.30 \pm 0.45$ & & $85.50 \pm 0.27$ & & $76.00 \pm 0.05$ \\
\hline & $10-2,8$ & & $10-5,25$ & & $10-1,10$ & \\
\hline & $10-67,7$ & $92.00+0.31$ & $11-1,5$ & $88.70 \pm 0.6$ & $10-1,70$ & $84.20 \pm 4.55$ \\
\hline \multirow{2}{*}{ D. brouweri LAD } & $10-6,68$ & & $11-1,100$ & & $11-1,10$ & \\
\hline & $11-5,104$ & & $13-2,120$ & & $14-1,10$ & \\
\hline \multirow[t]{3}{*}{ D. pentaradiatus LAD } & & $101.00 \pm 0.2$ & & $110.60 \pm 0.2$ & & $118.10 \pm 0.3$ \\
\hline & $11-5,145$ & & $13-3,15$ & & $14-1,70$ & \\
\hline & $11-5,104$ & & $13-3,58$ & & $14-1,10$ & \\
\hline \multirow[t]{2}{*}{ D. surculus LAD } & & $101.00 \pm 0.2$ & & $111.49 \pm 0.2$ & & $118.10 \pm 0.3$ \\
\hline & $\begin{array}{l}11-5,145 \\
11-6,23\end{array}$ & & $\begin{array}{l}13-3,100 \\
14-2,25\end{array}$ & & $\begin{array}{l}14-1,70 \\
15-1,10\end{array}$ & \\
\hline \multirow[t]{3}{*}{ D. tamalis LAD } & & $102.30 \pm 0.78$ & & $119.22 \pm 0.17$ & & $127.80 \pm 0.3$ \\
\hline & $12-1,9$ & & $14-2,60$ & & $15-1,70$ & \\
\hline & $14-3,103$ & & $17-5,25$ & & $18-5,70$ & \\
\hline \multirow[t]{3}{*}{ Sphenolithus spp. LAD } & & $126.70 \pm 0.42$ & & $152.00 \pm 0.17$ & & $163.20 \pm 0.45$ \\
\hline & $14-4,38$ & & $17-5,60$ & & $18-6,10$ & \\
\hline & $15-1,57$ & & $18-1,120$ & & $19-3,70$ & \\
\hline \multirow[t]{2}{*}{ R. pseudoumbilica LAD } & & $132.70 \pm 0.31$ & & $156.60 \pm 0.27$ & & $169.95 \pm 0.45$ \\
\hline & $15-1,119$ & & $18-2,25$ & & $19-4,10$ & \\
\hline \multirow[t]{3}{*}{ P. lacunosa FAD } & & $135.00 \pm 0.71$ & & $165.60 \pm 0.27$ & & $179.10 \pm 0.45$ \\
\hline & $15-3,83$ & & $19-2,25$ & & $20-4,10$ & \\
\hline & $15-4,128$ & & $19-4,100$ & & $20-4,10$ & \\
\hline D. asymmetricus FCO & & $138.50 \pm 0.87$ & & $169.90 \pm 0.37$ & & $179.90 \pm 0.3$ \\
\hline & $15-5,20$ & & $19-5,25$ & & $20-4,70$ & \\
\hline Amaurolithus spp. LCO & $16-4,110$ & 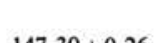 & $21-2,120$ & 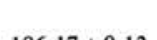 & $23-2,70$ & 0040007 \\
\hline Amaurolithus spp. LCO & $16-5.13$ & $147.30 \pm 0.26$ & 213.25 & $186.17 \pm 0.13$ & $23-3,10$ & $206.50 \pm 0.7$ \\
\hline & $16-5,116$ & & $21-3,120$ & & $23-1,10$ & \\
\hline H. selli FAD & & $150.00 \pm 1.39$ & & $187.67 \pm 0.27$ & & $204.20 \pm 0.3$ \\
\hline & $17-1,23$ & & $21-4,25$ & & $23-1,70$ & \\
\hline
\end{tabular}

(190.26 mbsf) are here pointed out. Such a presence of $G$. puncticulata below its continuous and common occurrence is here reported for the first time. However it is not clear, for the moment being, if it is due to down-reworking or if it represents a real stratigraphic occurrence. The disappearance of $G$. puncticulata is easily detected in sample $17-1,136 \mathrm{~cm}$ (146.96 mbsf); it is preceded by a short interval during which the abundance of the species gradually decreases. Just below the FO of G. puncticulata, the disappearance of Globigerina nepenthes is recognized (Sample 21-3, $75 \mathrm{~cm} ; 186.95 \mathrm{mbsf}$ ). A similar position is found in all the studied Mediterranean deep-sea and land sections.
The FO of Globorotalia bononiensis is recognized in Sample $16-2,75 \mathrm{~cm}$ (138.36 mbsf), where the species is common. It is slightly preceded by the FO of Globorotalia crassaformis s.l., which is recognized in Sample 16-3, 75 (139.86 mbsf). In its range the $G$. bononiensis morphotype is dominant, but it is generally associated with morphotypes interconnected with $G$. puncticulata (in the lower part of the range) or with Globorotalia inflata (in the upper part of the range). The coexistence of these morphotypes in the range of $G$. bononiensis was noted by Spaak (1981). G. bononiensis disappears in Sample 13-1, $36 \mathrm{~cm}$, at 109.06 mbsf. Within the $G$. crassaformis group, Globorotalia 


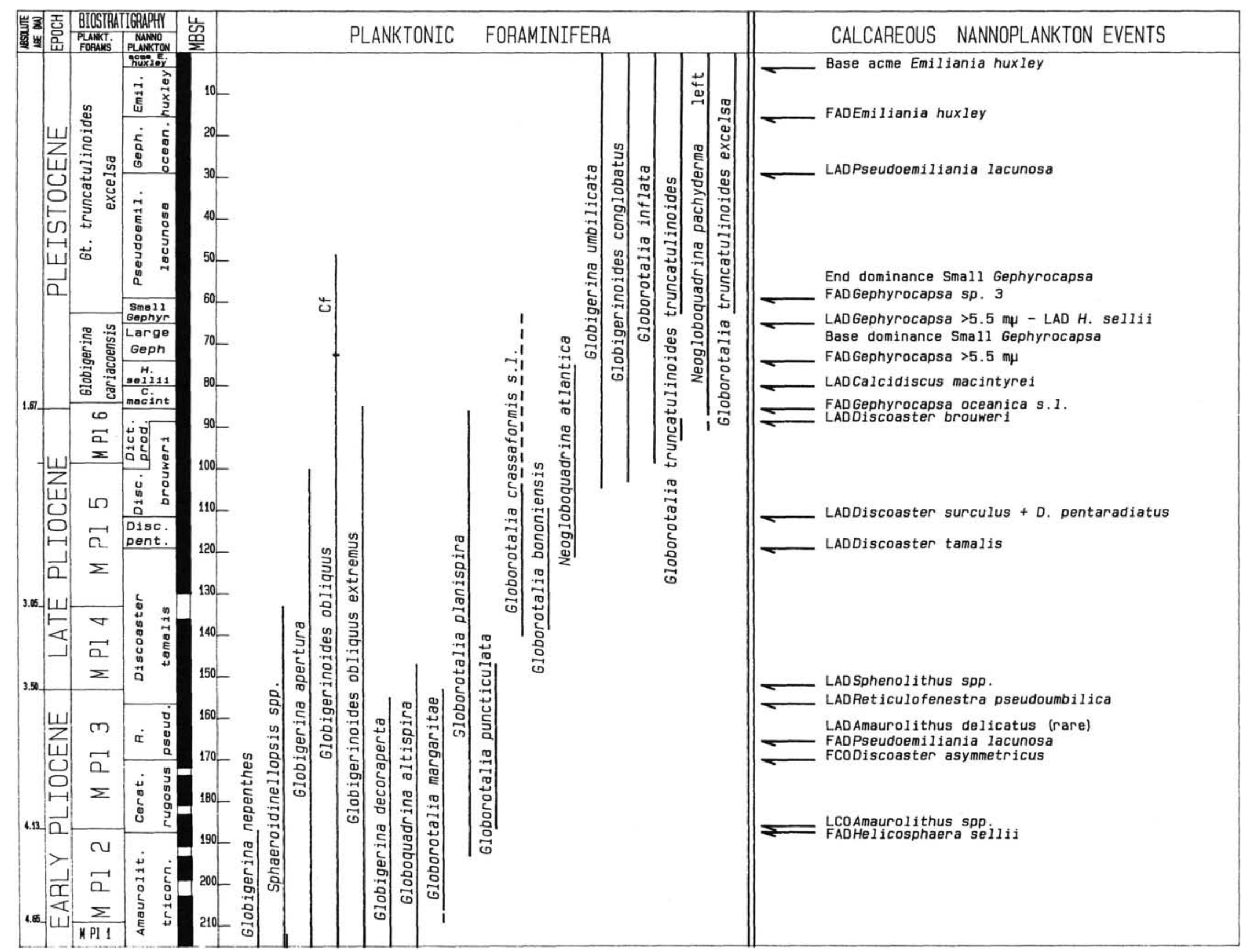

Figure 2. Hole 653A. Range chart of selected planktonic foraminifers and levels of calcareous nannofossil biostratigraphic events. Black bars $=$ recovery. 


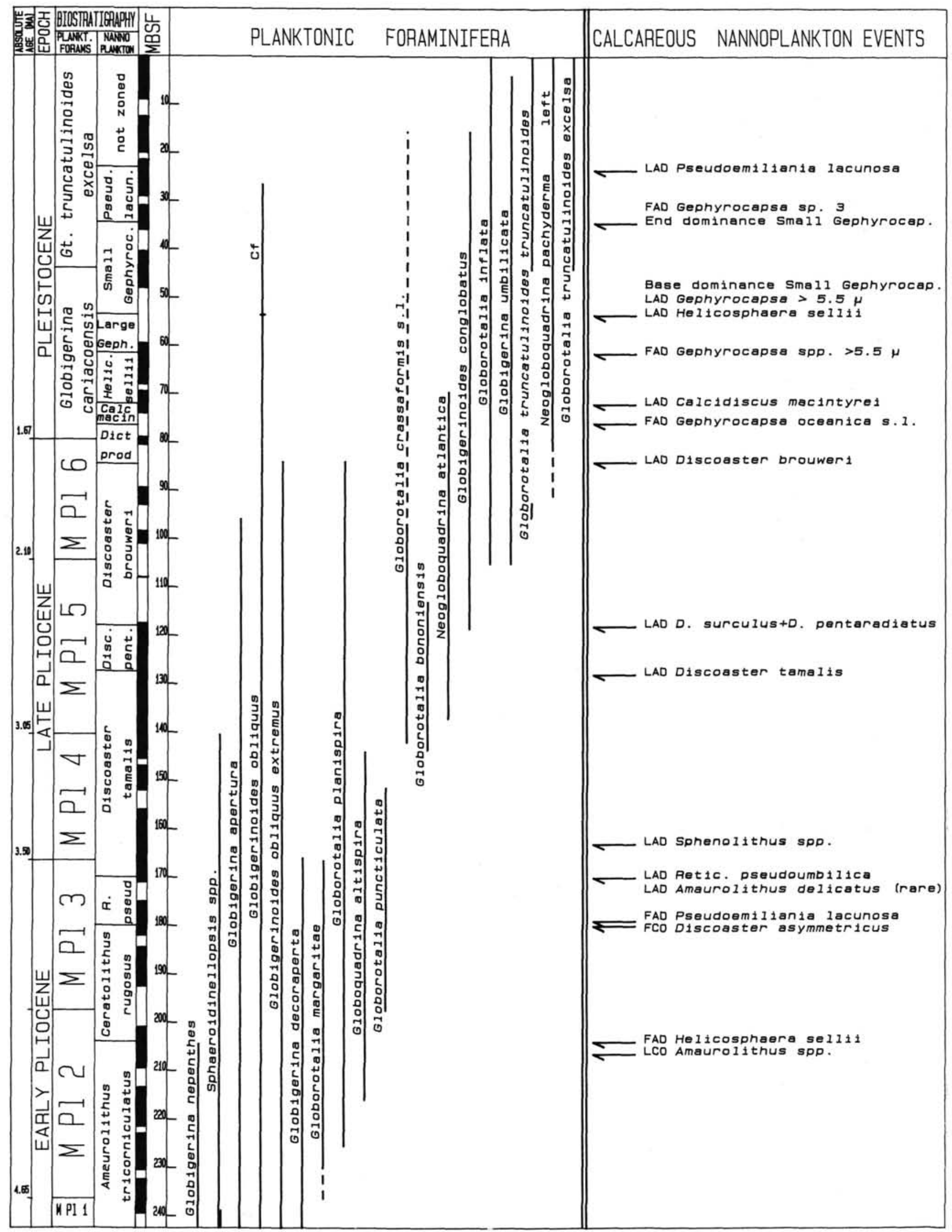

Figure 3. Site 654. Range chart of selected planktonic foraminifers and levels of calcareous nannofossil biostratigraphic events. Black bars $=$ recovery. 


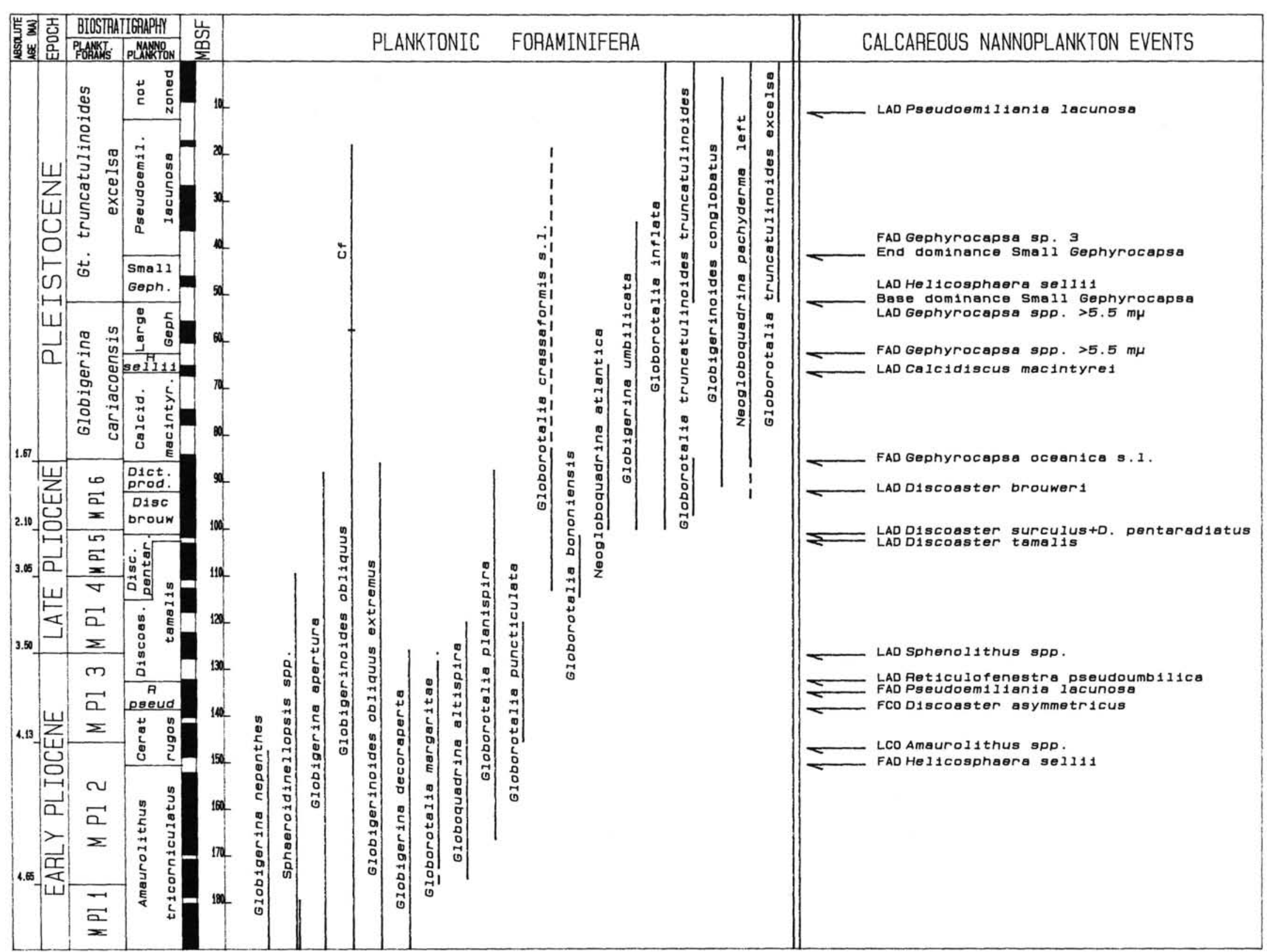

Figure 4. Site 652. Range chart of selected planktonic foraminifers and levels of calcareous nannofossil biostratigraphic events. Black bars $=$ recovery. 
Table 2. Samples and depth levels of the main planktonic foraminifers biostratigraphic events. Depth levels placed in unrecovered intervals are in brackets.

\begin{tabular}{|c|c|c|c|c|c|c|}
\hline & \multicolumn{2}{|c|}{ Site 652} & \multicolumn{2}{|c|}{ Site 653} & \multicolumn{2}{|c|}{ Site 654} \\
\hline & Sample & $\begin{array}{l}\text { Depth } \\
\text { (mbsf) }\end{array}$ & Sample & $\begin{array}{l}\text { Depth } \\
\text { (mbsf) }\end{array}$ & Sample & $\begin{array}{l}\text { Depth } \\
\text { (mbsf) }\end{array}$ \\
\hline Globorotalia truncatulinoides excelsa FO & 6-CC & $(51.50)$ & $8-2,91$ & 62.91 & $6-3,70$ & 44.00 \\
\hline Globigerinoides obliquus LO & $7-2,110$ & 58.00 & $9-2,75$ & 72.25 & $8-1,70$ & $(53.50)$ \\
\hline Neogloboquadrina atlantica $\mathrm{LO}$ & $8-1,36$ & $(62.50)$ & $9-4,75$ & 75.25 & $8-\mathrm{CC}$ & $(68.30)$ \\
\hline Neogloboquadrina pachyderma left common FO & $10-1,69$ & 84.90 & $10-4,15$ & 84.25 & $10-1,70$ & 79.70 \\
\hline Globigerinoides. obliquus extremus LO & $10-2,69$ & 86.40 & $10-4,75$ & 84.85 & $10-\mathrm{CC}$ & $(84.00)$ \\
\hline Globorotalia planispira LO & $10-3,68$ & 87.90 & $10-5,15$ & 85.75 & $10-\mathrm{CC}$ & $(84.00)$ \\
\hline Globorotalia truncatulinoides FO & $11-3,9$ & 96.90 & $11-4,31$ & 93.82 & $11-\mathrm{CC}$ & $(95.50)$ \\
\hline Globorotalia inflata $\mathrm{FO}$ & $11-5,33$ & 100.33 & $12-1,19$ & 98.40 & $12-\mathrm{CC}$ & $(105.00)$ \\
\hline Globigerina umbilicata $\mathrm{FO}$ & $11-5,18$ & 100.18 & $12-5,10$ & 104.30 & $12-2,70$ & $(105.00)$ \\
\hline Globorotalia bononiensis LO & $11-5,145$ & 101.24 & $13-1,36$ & 109.06 & $13-\mathrm{CC}$ & $(113.00)$ \\
\hline Neogloboquadrina atlantica $\mathrm{FO}$ & $11-5,18$ & 100.18 & $14-3,15$ & 120.46 & $15-\mathrm{CC}$ & 136.90 \\
\hline Sphaeroidinellopsis spp. LO & $12-5,68$ & 109.70 & $16-1,15$ & $(133.00)$ & $16-3,37$ & 140.93 \\
\hline Globorotalia bononiensis FO & $13-2,9$ & 114.30 & $16-2,75$ & 138.36 & $16-5,70$ & 143.60 \\
\hline Globorotalia crassaformis s.l. FO & $13-1,9$ & 112.80 & $16-3,75$ & 139.86 & $16-4,70$ & 142.10 \\
\hline Globorotalia puncticulata LO & $13-\mathrm{CC}$ & 120.0 & $17-1,136$ & 146.96 & $17-4,69$ & 151.60 \\
\hline Globorotalia margaritae LO & $14-3,117$ & 126.47 & $17-6,15$ & 153.26 & $19-1,70$ & 166.50 \\
\hline Globorotalia puncticulata FO & $16-4,80$ & 146.80 & $21-3,15$ & 186.35 & $22-\mathrm{CC}$ & (197.50) \\
\hline Globigerina nepenthes $\mathrm{LO}$ & $16-4,11$ & 147.06 & $21-3,75$ & 186.95 & $23-1,70$ & 204.50 \\
\hline Globorotalia planispira FO & $18-4,101$ & 166.31 & $21-\mathrm{CC}$ & (191.13) & $25-2,70$ & 225.30 \\
\hline Globorotalia margaritae FOD & $19-5,18$ & 176.25 & $23-5,91$ & 208.96 & $26-3,70$ & 236.40 \\
\hline Sphaeroidinellopsis spp. End Acme & $20-1,12$ & (180.33) & $23-\mathrm{CC}$ & 211.90 & $26-5,10$ & 238.80 \\
\hline
\end{tabular}

crassaformis aemiliana appears in Sample 16-2, $15 \mathrm{~cm} 7.76$ mbsf), and is discontinuously present up to Sample $11-7,15 \mathrm{~cm}$ (98.16 mbsf).

The Sphaeroidinellopsis spp. LO, coincident with the top of MPI4 biozone (Sphaeroidinellopsis subdehiscens biozone), is recorded in Sample 16-1, $15 \mathrm{~cm}$, just below an unrecovered inter$\mathrm{val}$ at the base of Core 15. It is therefore placed in the middle part of the unrecovered interval, at 133 mbsf. In land-based and deep-sea sequences in the Mediterranean region, the Sphaeroidinellopsis spp. LO is always detected just above the FO of $G$. bononiensis (Rio et al. 1984a). Sphaeroidinellopsis spp. are rare in the uppermost part of their range at Hole 653A.

Neogloboquadrina atlantica first occurs in Sample 14-3, $15 \mathrm{~cm}$ (120.46 mbsf). All along its range, up to Sample $9-4,75 \mathrm{~cm}$ (75.25 mbsf) it is sparse and discontinuous in the samples. Only in Samples 14-3, $15 \mathrm{~cm}$ (120.46 mbsf), 13-3, $15 \mathrm{~cm}$ (110.86 mbsf), 13-2, $75 \mathrm{~cm}$ (109.96 mbsf), and 12-4, $10 \mathrm{~cm}(102.80$ mbsf) is this species common to abundant.

The five-chambered, widely umbilicate Globigerina umbilicata appears in Sample 12-5, $10 \mathrm{~cm}(104.30 \mathrm{mbsf})$. It is generally scattered and in low frequency.

Rare Globorotalia inflata specimens, with well rounded test and wide aperture, appear in Sample 12-1, $19 \mathrm{~cm}$ (98.40 mbsf). From this level upward, the species is present, with more or less frequent specimens, up to the top of the sequence. However it is rare or absent in the intervals between 97 and 94.50 mbsf, 91 and $88 \mathrm{mbsf}$, and 3 and $0.35 \mathrm{mbsf}$. A few meters above its FO, an interval from Sample $11-4,15 \mathrm{~cm}$ (93.66 mbsf) to Sample $10-6,75 \mathrm{~cm}$ ( $87.85 \mathrm{mbsf})$ is characterized by common specimens of Globorotalia truncatulinoides, Globorotalia tosaensis, and Sphaeroidinella dehiscens. This well characterized level represents a useful biostratigraphic horizon, near the base of MP16 (Globorotalia inflata biozone), recognized in eastern and western Mediterranean both in deep-sea and in land-based sequences (Rio et al., 1984b).

The Globorotalia planispira, Globigerinoides obliquus extremus LO's, and the first common occurrence of Neogloboquadrina pachyderma left coiling follow each other, in this order, in a very short sedimentary interval, between Sample $10-5,15 \mathrm{~cm}$ (85.75 mbsf), where G. planispira disappears and Sample 10-4, $15 \mathrm{~cm}$ ( $84.24 \mathrm{mbsf})$, where the first common specimens of left coiling N. pachyderma are present. The last specimens of Globi- gerinoides obliquus extremus were found in Sample 10-4, $75 \mathrm{~cm}$ ( $84.85 \mathrm{mbsf}$ ). As discussed below, the very closely spaced distribution of these three events may indicate the presence of a short gap in the stratigraphic sequence.

In Sample 9-2, $75 \mathrm{~cm}$ (72.25 mbsf), the last rare, small sized specimens of Globigerinoides obliquus occur. Above its disappearance level, rare specimens identified as Globigerinoides cf. obliquus are present in some samples. They have a considerably more elongated spire and a larger aperture and are similar to the morphotype illustrated from the DSDP Site 125 by Raffi and Sprovieri (1984; Pl. 3, Figs. 6-8) as Globigerinoides sp. aff. Globigerinoides obliquus.

The last planktonic foraminiferal biostratigraphic event occurs in Sample 8-2, $91 \mathrm{~cm}$ (62.91 mbsf), where the first rare specimens of Globorotalia truncatulinoides excelsa occur. This species occurs together with Globorotalia truncatulinoides truncatulinoides, which reentered the Mediterranean basin at this time interval, after its disappearance in the basal part of MP16. At Hole $653 \mathrm{~A}$, these two species are generally rare and scattered up to the top of Core 5 (about $35 \mathrm{mbsf}$ ), but are more abundant and continuously present above this level. The appearance of Globigerina cariacoensis was proposed as a biostratigraphic marker for the recognition of the Pliocene-Pleistocene boundary (Colalongo et al., 1982). In our material, this species is always very rare and scattered, and therefore this event cannot be consistently used. Globigerinoides tenellus is also very rare and scattered, and therefore its first occurrence in the sequence is not significant. In the late Pliocene Globorotalia incisa is also generally rare and scattered.

\section{Site 654}

Because of the low recovery, biostratigraphic classification of Site 654 is not as detailed as that at Site 653 , and several events are placed within unrecovered intervals. All the biostratigraphic events recognized at Site 653 are present. In Figure 3, the range of selected species is reported with the biostratigraphic and chronostratigraphic subdivision of the sequence. In Table 2, the samples and relative depth corresponding to the main biostratigraphic events are reported. Comments on the distribution of some selected species follows below.

The top of the acme of Sphaeroidinellopsis spp. is recorded in Sample $26-5,10 \mathrm{~cm}$ (238.80 mbsf), closely followed by the FO 
of G. margaritae in Sample $26-3,70 \mathrm{~cm}$ (236.40 mbsf). This species is rare and scattered in the basal interval of its range, up to Sample $25-$ CC (232.70 mbsf). It is then common and more or less continuously present up to Sample 20-1, $70 \mathrm{~cm}(175.70$ mbsf). From this level upward, G. margaritae is rare and scattered again up to Sample 19-1, $70 \mathrm{~cm}$ (166.50 mbsf), where it disappears. In Sample 22-CC, the first specimens of G. puncticulata are recorded. Since this level falls at the base of a long unrecovered interval of all the Core 22 , the FO level of $G$. puncticulata is placed in the middle of this interval, at $197.50 \mathrm{mbsf}$. Rare specimens of Globorotalia puncticulata are noted in Sample $23-1,9 \mathrm{~cm}$ (203.98 mbsf), but their presence is not explained at this time. The disappearance of $G$. puncticulata is recorded in Sample $17-4,69 \mathrm{~cm}$, at $151.60 \mathrm{mbsf}$. The species is rare in the topmost part of its range. Globigerina nepenthes disappears, below the $G$. puncticulata FO, in Sample 23-1, $70 \mathrm{~cm}(204.50$ mbsf). The FO of $G$. puncticulata is generally recorded just above the LO of $G$. nepenthes. Therefore the FO of $G$. puncticulata in Site 654 ought to be evaluated near the base of the unrecovered interval.

The $G$. bononiensis $\mathrm{FO}$ is placed in Sample $16-5,70 \mathrm{~cm}$ (143.60 mbsf), based on common and typical specimens. Its LO is in Sample 13-CC, just below an unrecovered interval; therefore its disappearance level is placed within this interval, at 113 mbsf. As in Site 653, the $G$. bononiensis morphotype prevails through its range but is associated with morphotypes interconnected with $G$. punticulata in the lower part and with morphotypes interconnected with $G$. inflata in the upper part. Just above the $G$. bononiensis FO, Globorotalia crassaformis s.l. appears. In this group, Globorotalia crassaformis aemiliana appears in Sample 17-1, $69 \mathrm{~cm}$ (147.10 mbsf), and disappears in Sample 12-CC (118 mbsf). In Sample 16-3, $37 \mathrm{~cm}$ (140.93 mbsf), the last occurrence of Sphaeroidinellopsis spp. is recognized, indicating the MPI4/MPI5 boundary.

Neogloboquadrina atlantica appears in Sample 15-CC (136.90 mbsf); it ranges up to Sample 8-CC, and its LO level is evaluated at 68.30 mbsf, within the unrecovered interval of Core 8 . $N$. atlantica is generally rare and scattered in the samples, but is common to abundant in Samples 13-CC (117.70 mbsf), and 10$1,70 \mathrm{~cm}$ (79.70 mbsf).

The first occurrence of Globigerina umbilicata is in Sample $12-2,70 \mathrm{~cm}$, and its appearance level is placed at $105 \mathrm{mbsf}$ within the unrecovered interval of Core 12 . The $G$. inflata FO is recorded in Sample 12-CC, at the base of the same unrecovered interval. Therefore, this event is also placed in the middle part of this unrecovered interval, at 105 mbsf. In all known Mediterranean deep-sea and land-based sections the FO of G. umbilicata predates the FO of $G$. inflata. Therefore it may be concluded that the first specimens of G. umbilicata recognized in Sample $12-2,70 \mathrm{~cm}$, do not correspond to the first appearance of this species, which most probably first occurred in the long unrecovered interval of Core 13.

A short interval with $G$. truncatulinoides, G. tosaensis, and Sphaeroidinella dehiscens was recognized between Samples 11-CC and 11-3, $70 \mathrm{~cm}$ (between 95.50 and $92.40 \mathrm{mbsf}$ ). The appearance of $G$. truncatulinoides occurs at the base of an unrecovered interval and therefore its appearance level is placed within this interval, at $95.50 \mathrm{mbsf}$.

The LO's of G. planispira and Globigerinoides obliquus extremus are in Sample 10-CC, just below the unrecovered interval of Core 10. The level of these events is therefore placed at 84 mbsf. The first common occurrence of left coiling N. pachyderma (used to recognize the Pliocene-Pleistocene boundary at Site 654), is recorded in Sample 10-1, $70 \mathrm{~cm}$ (79.70 mbsf). In Sample 8-1, $70 \mathrm{~cm}$ ( $53.50 \mathrm{mbsf})$, the last, rare, small sized specimens of Globigerinoides obliquus are recorded, below the long unrecovered interval of Core 7 . This event is therefore placed within this interval, at 53.50 mbsf. Above its LO level rare specimens identified as Globigerinoides cf. obliquus are present and rare, as in the same stratigraphic interval of Site 653. The $G$. truncatulinoides excelsa first appearance level is in Sample 6-3, $70 \mathrm{~cm}$ (44.00 mbsf), where it is associated with $G$. truncatulinoides truncatulinoides. Both species are rare and scattered in the lower part of their range and become frequent and continuously present from the lower part of Core 3 .

As at Site 653, G. cariacoensis, $G$. tenellus, and $G$. incisa are always rare and scattered and therefore of limited biostratigraphic utility.

\section{Site 652}

Also at this Site, because of the low recovery, the biostratigraphic classification is not as detailed as at Site 653. However, all the biostratigraphic events recognized in the other two Sites have been detected. In Figure 4 the range chart of selected species is reported together with the biostratigraphic and chronostratigraphic classification of the sequence. In Table 2 the main biostratigraphic events and relative mbsf are reported. Comments on the distribution on selected species follow below.

The end of the acme of Sphaeroidinellopsis spp. is recognized in Sample 20-1, $12 \mathrm{~cm}$, just below a small unrecovered interval at the base of Core 19; it is therefore placed at 180.33 mbsf. At this site, this event is $9.48 \mathrm{~m}$ above the base of the Pliocene, as recognized by the re-establishment of permanent open marine condition in the Mediterranean basin (Cita 1975). Therefore the stratigraphic interval at the base of the Pliocene characterized by the Sphaeroidinellopsis spp. acme is well developed in Site 652 and probably better represented than at Sites 653 and 654.

The G. margaritae FO occurs in Sample 19-5, $18 \mathrm{~cm}(176.25$ mbsf), about $4 \mathrm{~m}$ above the end of the Sphaeroidinellopsis spp. acme. In the basal part of its range, up to Sample 18-CC (170.70 mbsf), G. margaritae is rare and not continuously present. From this level upward, the marker is more abundant and continuously present up to Sample $15-2,15 \mathrm{~cm}$ (133.55 mbsf); it is then again rare and scattered up to Sample 14-3, $117 \mathrm{~cm}$ (126.47 mbsf). The first, abundant specimens of $G$. puncticulata occur in Sample 16-4, $80 \mathrm{~cm}$ (146.80 mbsf). Again, rare specimens occur below the first common occurrence of $G$. puncticulata, in Sample 17-2, $145 \mathrm{~cm}$ (154.75 mbsf), as at Sites 653 and 654. The LO of G. puncticulata is in Sample 13-CC; because it occurs just below an unrecovered interval, this event is placed within this interval at 120.00 mbsf.

The $G$. bononiensis FO is in Sample 13-2, $9 \mathrm{~cm}(114.30$ mbsf), just below the FO of G. crassaformis s.l. in Sample 13-1, $9 \mathrm{~cm}$ (112.80 mbsf). Again G. bononiensis morphotype prevails, but morphotypes close to $G$. puncticulata are present in the lower part and morphotypes close to $G$. inflata are present in the upper part of the range of $G$. bononiensis. The $G$. bononiensis LO is in Sample 11-5, $145 \mathrm{~cm}$ (101.24 mbsf), close to the FO of $G$. inflata. Within the $G$. crassaformis group, $G$. crassaformis aemiliana appears in Sample 12-CC (112.70 mbsf) and disappears in Sample 11-6, $9 \mathrm{~cm}$ (110.67 mbsf).

Sphaeroidinellopsis spp. disappear in Sample 12-5, $68 \mathrm{~cm}$ ( $109.70 \mathrm{mbsf}$ ), where the top of MPl4 biozone is recognized. Specimens of this genus are rare in the uppermost part of its range.

The first occurrence of Neogloboquadrina atlantica is in Sample $11-5,18 \mathrm{~cm}$ (100.18 mbsf), together with the FO of $G$. umbilicata. The G. inflata FO is in Sample $11-5,33 \mathrm{~cm}(100.33$ mbsf). From the analysis of Site 653 and of several land-based sections, it is well established that the appearance levels of these three species are well spaced. Therefore we infer the presence of a long sedimentary gap in this part of the sequence at Site 652. The LO of $N$. atlantica is in Sample 8-1, $36 \mathrm{~cm}$, just above an 
unrecovered interval. In the interval between Sample 11-3, $9 \mathrm{~cm}$ ( $96.90 \mathrm{mbsf})$ and Sample 11-1, $35 \mathrm{~cm}$ (94.15 mbsf) Globorotalia truncatulinoides is present with $G$. tosaensis and Sphaeroidinella dehiscens. Globorotalia planispira LO is in Sample 10-3, $68 \mathrm{~cm}$ ( $87.90 \mathrm{mbsf})$, followed by the LO of Globigerinoides obliquus extremus in Sample 10-2, $69 \mathrm{~cm}$ (86.40 mbsf). The appearance of the first common left coiling $N$. pachyderma specimens is in Sample 10-1, $69 \mathrm{~cm}$ (84.90 mbsf). As in Hole 653A, the close occurrence of these events is indicative of a short sedimentary gap, as discussed below. The Globigerinoides obliquus LO is in Sample 7-2, $110 \mathrm{~cm}$ (58.00 mbsf). Above its LO, rare specimens of Globigerinoides cf. obliquus, as in Site 653 and Site 654 , were found.

Globorotalia truncatulinoides excelsa first occurs in Sample 6-CC and this event is placed in the above unrecovered interval, at 51.50 mbsf. This species, together with $G$. truncatulinoides truncatulinoides, is rare and scattered in the lower part of its range and becomes more frequent and continuously present from the upper part of core 4.

Also at Site 652 the distribution of Globigerina cariacoensis, Globigerinoides tenellus, and Globorotalia incisa are too rare and scattered to be useful.

\section{DISCUSSION}

The availability of events based on two different fossil groups in three sedimentary sequences permits facing the problem of traceability, ranking, and scaling of calcareous plankton biostratigraphic events.

Different numerical and graphic techniques have been proposed recently for resolving these classical problems of biostratigraphy (Gradstein et al., 1985). In this section, however, we simply present a basic correlation scheme among the three investigated sections based on events discussed previously. This permits a preliminary evaluation of traceability and scaling of considered events.

Not surprisingly, considering the location of the three studied sequences in the same basin, the events we have monitored are well traceable in all three investigated sequences. Most, if not all, are also easily traced to Italian land-sections. In Figure 5 we have traced correlations among the three sequences, using the events listed in Table 3 . If the events were all in the same order and synchronous and the sediment accumulation rate were constant and identical within the single sections, correlations lines would parallel each other. Any departure from this parallelism can derive from diachroneity of the events or varying sediment accumulation rate in the sequences. Any crossing of the correlation lines implies that the ranking of the events is different in the considered sections. Following is a brief discussion which is meant mainly to check the ranking of the events. A proper evaluation of the spacing and accuracy in time of the bioevents, can not be carried out with the plot of Figure 5 .

If we consider the relative sequence of the events within each of the two groups, no crossing lines are detected except for the Amaurolithus spp. LCO and H. sellii FAD between Sites 654 and Site 653 in the nannofossil assemblage and for the FO of Globorotalia crassaformis group and the FO of Globorotalia bononiensis in the foraminifers. We note, however, that these events are close to each other and that no major diachroneity is involved on the basis of data presented here. The Amaurolithus spp. FCO is a difficult event to pinpoint as discussed in Rio, Raffi, and Villa (this volume), and can be considered only as a second order event. As for the Globorotalia crassaformis group, major diachroneities in the appearances of these species, with strong ecological control, are reported in the literature (Cita, 1973; Rio et al., 1984a). Although no major discrepancies, and therefore no major diachroneities, exist in the sequence of the events in Figure 5, it cannot be excluded that minor diachro- neities could still be present within the intervals of the utilized correlation lines.

The employment of both groups of events increase significantly the number of correlation lines, and we obtain a better evaluation of synchroneity. The correlation lines reported in Figure 5 prove that 29 out of the 32 considered events maintain their relative position suggesting that no major diachroneities exist within the Tyrrhenian Sea.

A special comment is in order for the first appearance of abundant left coiling specimens of Neogloboquadrina pachyderma. At Site 654 this event predates the entrance of Gephyrocapsa oceanica s.l. as it does in the classical Italian sections like Vrica and Capo Rossello (Rio, Backman, and Raffi, in press). On the contrary, both at Site 653 and 652 , it is recorded after the FAD of $G$. oceanica s.l. The $N$. pachyderma left coiling event, as utilized here and generally applied in mainland Italian sections, is defined as the first abundant occurrence of left coiling specimens of the species. However, right and left specimens of $N$. pachyderma show highly fluctuating abundance patterns throughout the Pleistocene, and we interpret the reversal of the event with respect to $G$. oceanica s.l. as due to short hiatuses in Sites 653 and 652 , which prevent the detection of the first abundance peak of left coiling $N$. pachyderma. This suggestion is in agreement with the short spacing between the Discoaster brouweri LAD and $G$. oceanica s.l. FAD in both the sequences in comparison to Italian mainland sections and DSDP Site 132 (Raffi and Rio, 1979).

\section{CONCLUSIONS}

We have presented quantitatively and semiquantitatively collected data on the stratigraphic distribution of stratigraphically indicative planktonic foraminifers and calcareous nannofossils in the Pliocene and Pleistocene records of ODP Sites 652, 653, and 654 . The study of the two fossil groups, often based on the same samples, allows us (1) to establish the relative successions of the events based on the two fossil groups; (2) to improve biostratigraphic resolution by integrating the events provided by the two fossil groups; and (3) to evaluate possible anomaly in the succession of the events.

By correlating biostratigraphic events in the investigated sections, we have shown that 29 nonrepetitive and distinct bioevents are present, which provide an high degree and sound stratigraphic resolution in the Mediterranean Pliocene-Pleistocene record.

\section{ACKNOWLEDGMENTS}

We thank K. A. Kastens, J. Mascle, W. F. Ruddiman, and W. J. Zachariasse for the critical review of the manuscript. This paper was supported by Italian CNR, Grant no. 87.0087.05 to R. Sprovieri and Grant no. 87.00889.05 to D. Rio.

\section{REFERENCES}

Cita, M. B., 1973. Pliocene biostratigraphy and Chronostratigraphy. In Ryan, W.B.F., Hsü, K. J., et al.: Init. Repts. DSDP, 13: Washington (U.S. Govt. Printing Office), 1343-1379.

Cita, M. B., 1975. Studi sul Pliocene e gli strati di passaggio dal Miocene al Pliocene. VIII. Planktonic foraminiferal biozonation of the Mediterranean Pliocene deep sea record. A revision. Riv. It. Paleont. Strat., 81: 527-544.

Cita, M. B., 1975a. The Miocene/Pliocene boundary. History and definition. In: Saito, T. and Burckle, L. H. (Eds), Late Neogene Epoch Boundaries. Micropaleontology Press Spec. Publ., 1:1-30.

Colalongo, M. L., Pasini, G., Pelosio, G., Raffi, S., Rio, D., Ruggieri, G., Sartoni, S., Selli, R. and Sprovieri, R., 1982. The Neogene/ Quaternary Boundary definition: a Review and a Proposal. Geogr. Fis. Dinam. Quat., 5: 59-68.

Gradstein, F. M., Agterberg, F. P., Brower, J. C., Schwarzacher, W. S., 1985. Quantitative stratigraphy. Paris (Reidel Publishing Co.), 598 p. 
Martini, E., 1970. Standard Tertiary and Quaternary Calcareous Nannoplankton Zonation. In Farinacci, A. (Ed.), Proc. Planktonic Conf., 2nd, Roma, 2:739-785.

Okada, H., and Bukry, D., 1980. Supplementary modification and introduction of code numbers to the low-latitude Coccolith biostratigraphic zonation (Bukry, 1973, 1975). Mar. Micropaleontol., 5:321325.

Raffi, I., and Rio, D., 1979. Calcareous nannofossil biostratigraphy of DSDP Site 132-Leg 13 (Tyrrhenian Sea-Western Mediterranean). Riv. It. Paleontol. Strat., 85:127-172.

Raffi, I., and Sprovieri, R., 1984. Calcareous plankton in the DSDP Hole 1225-Leg 13 (Ionian Sea-Eastern Mediterranean): a review. Boll. Soc. Paleont. It., 23:53-73.

Rio, D., Backman, J., and Raffi, I., in press. Calcareous nannofossil biochronology and the Pliocene/Pleistocene boundary. In van Couvering (Ed.), The Neogene/Quaternary Boundary. Final Report of the IGCP Project n. 41.

Rio, D., Sprovieri, R. and Raffi, I., 1984a. Calcareous plankton biostratigraphy and biochronology of the Pliocene-Lower Pleistocene succession of the Capo Rossello area, Sicily. Mar. Micropaleontol., 9:135-180.

Rio, D., Sprovieri, R., Di Stefano E., and Raffi, I. 1984b. Globorotalia truncatulinoides (d'Orbigny) in the Mediterranean upper Pliocene geologic record. Micropaleontology, 30:121-137.

Ruggieri, G., Rio, D., and Sprovieri, R., 1984. Remarks on the chronostratigraphic classification of the Lower Pleistocene. Boll. Soc. Geol. It., 103:251-259.

Spaak, P., 1981. The distribution of the Globorotalia inflata group in the Mediterranean Pliocene. Proc. K. Nederl. Akad. Wet., 84:201215 .

Zijderveld, J.D.A., Zachariasse, J. W., Verhallen, P.J.J.M., and Hilgen, F. J., 1986. The age of the Miocene-Pliocene boundary. Newsl. Stratigr., 16:169-181.

Date of initial receipt: 7 April 1988

Date of acceptance: 17 January 1989

Ms 107B-148

Table 3. List of biostratigraphic events used for the biostratigraphic correlation of the three studied sequences.

\begin{tabular}{ll}
\hline \multicolumn{1}{c}{ Planktonic foraminifers } & \multicolumn{1}{c}{ Calcareous nannoplankton } \\
\hline 30 FO Globorotalia truncatulinoides excelsa & 32 LAD Pseudoemiliania lacunosa \\
27 LO Globigerinoides obliquus & 31 FAD Gephyrocapsa sp. 3 \\
23 FCO Neogloboquadrina pachyderma left & 29 Base dominance Small Gephyrocapsa \\
21 FO Globorotalia truncatulinoides & 28 LAD Helicosphaera sellii \\
20 FO GLoborotalia inflata & 26 FAD Gephyrocapsa $>5.5$ m \\
19 LO Globorotalia bononiensis & 25 LAD Calcidiscus macintyrei \\
16 LO Sphaeroidinellopsis spp. & 24 FAD Gephyrocapsa oceanica s.1. \\
15 FO Globorotalia crassaformis s.l. & 22 LAD Discoaster brouweri \\
14 FO Globorotalia bononiensis & 18 LAD Discoaster pentaradiatus \\
13 LO Globorotalia puncticulata & 17 LAD Discoaster tamalis \\
11 LO Globorotalia margaritae & 12 LAD Sphenolithus spp. \\
7 FO Globorotalia puncticulata & 10 LAD Reticulofenestra pseudoumbilica \\
6 LO Globigerina nepenthes & 9 FAD Pseudoemiliania lacunosa \\
3 FO Globorotalia planispira & 8 FCO Discoaster asynmmetricus \\
2 FO Globorotalia margaritae & 5 LCO Amaurolithus spp. \\
1 End acme Sphaeroidinellopsis spp. & 4 FAD Helicosphaera sellii \\
\hline
\end{tabular}




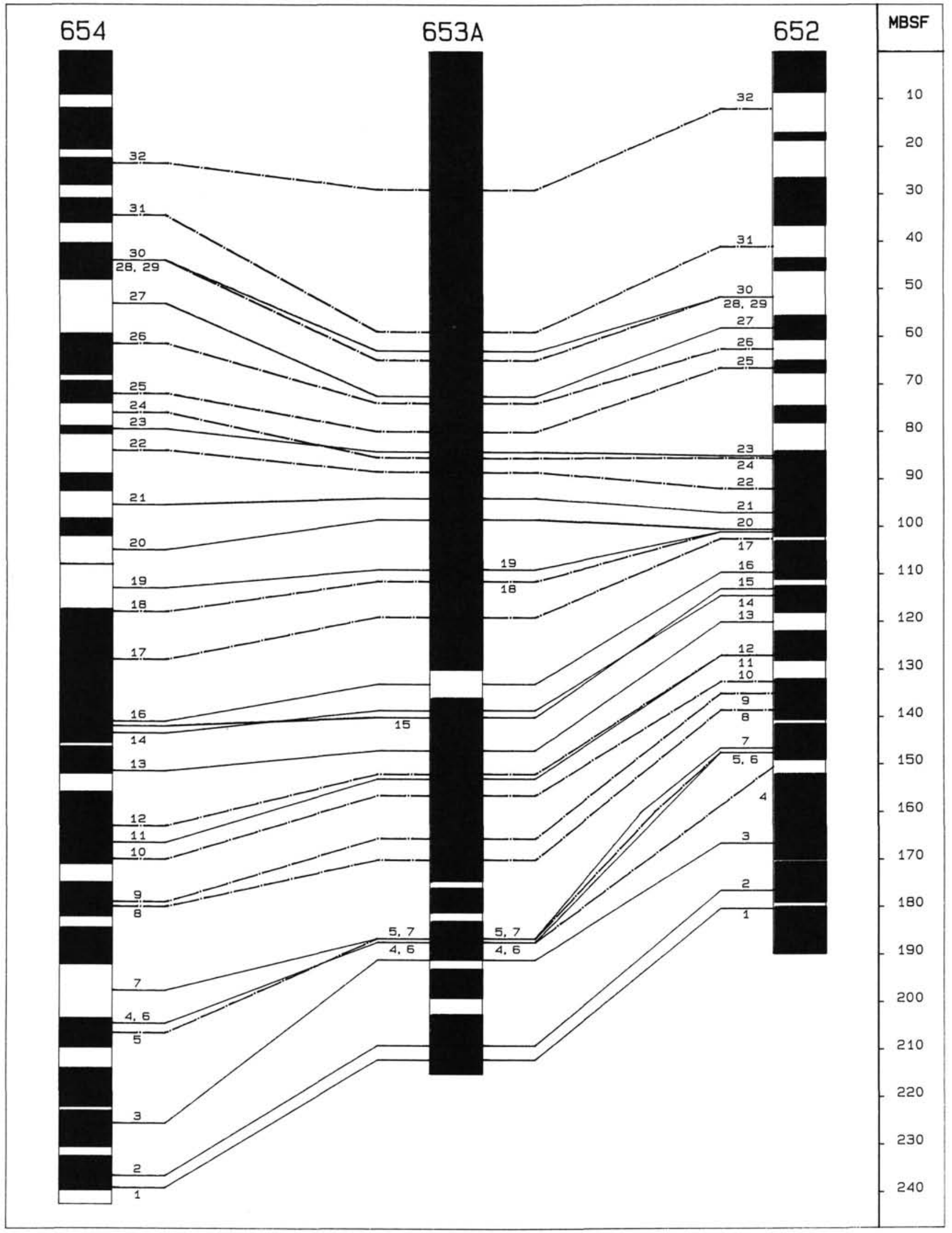

Figure 5. Biostratigraphic correlation of the three studied sequences based on the biostratigraphic events listed in Table 3 . 